\title{
Using Standard Work Tools For Process Improvement
}

\author{
Elaine J. Labach, Ph.D., Troy University
}

\begin{abstract}
The purpose of this paper is to describe the application of Kaizen tools toward process improvement. The key tools described are those dedicated toward standard work, which is a prescribed sequence of tasks which are balanced to achieve a level production schedule. Data from an actual Kaizen event in a Sewing Panel area serves as examples of the tools. Specific tools highlighted include Takt Time, Time Observation Sheet, Cycle Time Bar Chart, Standard Work Layout Diagram, Spaghetti Diagram, 6-S Audit Sheet and Standard Work Combination Sheet. The concept of a Cell Documentation Board is also presented to document and monitor standard work, and includes a Production Control Board and a Key Points Sheet.
\end{abstract}

Keywords: Process improvement, Standard work, Kaizen

\section{INTRODUCTION}

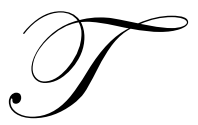

he Japanese term of Kaizen has been defined as Kai (to pull apart) and Zen (to put back together in harmony) and is a lean process improvement approach (Bradley and Willett, 2004; Melnyk et al, 1998; Sheridan, 1997 and Vasilash, 1997). Kaizen events are rapid (typically completed in 3-5 days) and low cost (implements low cost approaches to process improvement). Benefits of successful Kaizen application has been reported to include increases in productivity (300-400\%), increases in inventory turns (1000\%), reduction in defects (95\%) and lead time (95\%) (Cuscela, 1998; Sheridan, 1997). Through the involvement of cross functional teams, team members are educated in using the tools as well as experience the process of Kaizen. Kaizen focuses on quality improvement and elimination of waste in every form. By targeting wastes, Kaizen improves safety, quality, speed and method of processing by reducing: (1) injuries; (2) defects and processing waste; (3) overproduction, inventory or duplication and (4) transportation, motion, idle and wait time.

Proponents of Kaizen who have used it successfully as a lean approach report that it accomplishes process improvement with the best of human spirit. Through use of a disciplined, problem solving approach, blaming, faulting, scape-goating and finger pointing are de-emphasized. Kaizen encourages team members who have a healthy dissatisfaction with the way things are and gives them a process for defining and implementing improvements.

\section{STANDARD WORK}

\section{Introduction}

Standard work is a prescribed sequence of production steps or activities that are assigned to a single operator which are balanced to the takt time. Takt time is the net available time per shift (in seconds) divided by customer demand per shift (in units). The takt time serves as the pulse, or pace of production. Given that demand is leveled, takt time is the key to JIT (Just-in-Time) manufacturing since it spreads customer demand evenly across the time available.

The purpose of standard work is to minimize and control the variation in output, quality, WIP (Work in Process) inventory levels and cost. As previously mentioned, takt time is an important element of standard work. Cycle times, work sequence and standard WIP levels are also important elements. By defining these to balance the work to takt time, performance measures of the process are optimized. 
Prerequisites for standard work include: one piece flow cell; repeating work sequences; management/supervisor commitment; and a disciplined approach to tracking and addressing performance, especially that which deviates from prescribed levels.

We will look at examples of standard work taken from a sewing operation that makes panels for a finished product. The goals of this 5-day Kaizen event were as follows:

1. Develop a one-piece flow cell for making panels and reduce WIP by $20 \%$.

2. Increase productivity (as measured by pieces/man-hour) by $30 \%$.

3. Identify safety hazards and improve the 6-S assessment (target score is100\%).

\title{
Takt Time
}

For this particular example, the work needs to be accomplished in an eight-hour work day, with 30 minutes of break time and 10 minutes allowed for clean up. For each shift, 325 pieces of work must be completed to meet the customer demand, or the production schedule. The takt time calculation, which defines the number of seconds to allocate to each piece, is shown in Table 1 below.

\author{
Table 1: Example of Takt Time Calculation \\ 8 Hours $=480$ minutes \\ -30 minutes (break) \\ $\underline{-10 \text { minutes (clean-up) }}$ \\ Total 440 available minutes \\ 440 minutes available $\quad$ x 60 seconds/minute $=26,400$ seconds per shift \\ 26,400 seconds divided By customer demand of 325 pieces $/$ shift $=81.2$ seconds $/$ piece \\ Takt Time $=81$ seconds per piece
}

\section{Standard Work Tools}

The typical tools of standard work incorporate pace (Takt Time), work sequence (people) and standard work in process (pieces) and include the following:

$\circ \quad$ Time Observation Sheet (before and after improvements)

- $\quad$ Cycle Time Bar Chart (before and after improvements)

$\circ \quad$ Standard Work Layout Sheet (before and after improvements)

- Spaghetti Diagram (before improvement)

- 6-S Audit Sheet (before and after improvements)

$\circ \quad$ Standard Work Combination Sheet

- Production Control Board

$\circ \quad$ Key Points Sheet

\section{Time Observation Sheet}

Once the goals have been established and the team members have been trained, the first tool utilized is the Time Observation Sheet. Team members are assigned to collect typical times of various tasks associated with the Label station of the process in order to baseline its performance. Each operator is timed for 5 cycles to identify an average cycle time. Figure 1 shows an example time observation sheet completed for operator one. The average cycle time to complete the labeling operation is 49 seconds (lower right hand corner of Figure 1).

\section{Cycle Time Bar Chart}

Once individual cycle times are collected for each operator, a cycle time bar chart can be constructed (see Figure 2). This chart indicates not only how far each operator's cycle time differs from the takt time, but it also 
shows non-value activities being performed by the operators. By taking the sum of all operator's cycle times and dividing by the takt time, it shows a minimum staffing of three operators is needed (there are currently five operators).

Figure 1: Five Cycle Time Observations for Operator 1 in Panel Sewing Area

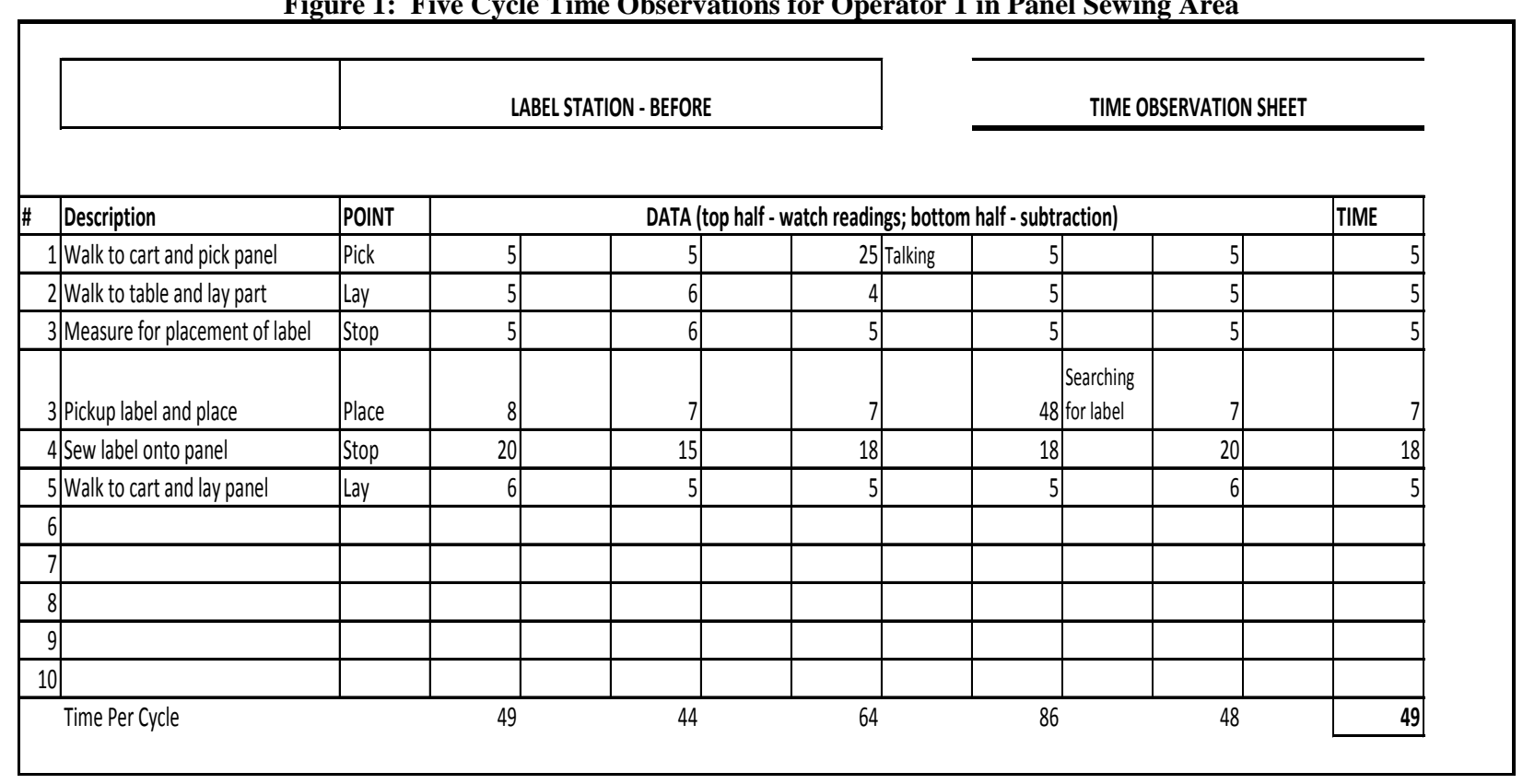

Figure 2: Cycle Time Bar Chart for Panel Sewing Area (Before Improvement)

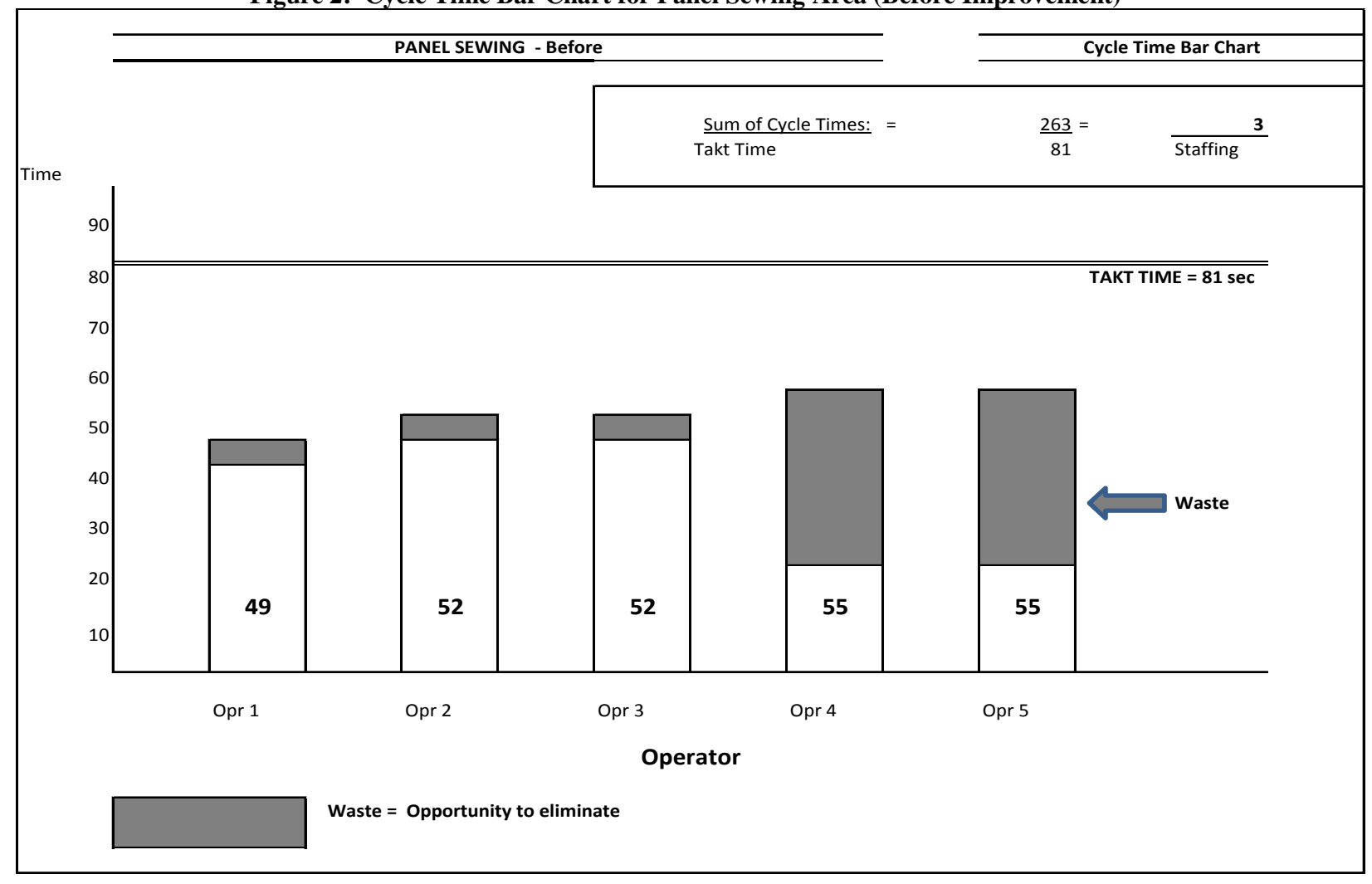




\section{Standard Work Layout and Spaghetti Diagrams}

Two other typical tools of Standard Work include the Layout and Spaghetti Diagrams. Figure 3 shows the layout of the sewing area before improvements have been made. Note that the material comes to the flange machine via carts, and once attached, travels down the conveyor to two inspection stations where a quality check is made. WIP is shown by dark circles and potential safety risks are shown by dark crosses.

Figure 3: Standard Work Layout of Panel Sewing Area (Before Improvement)

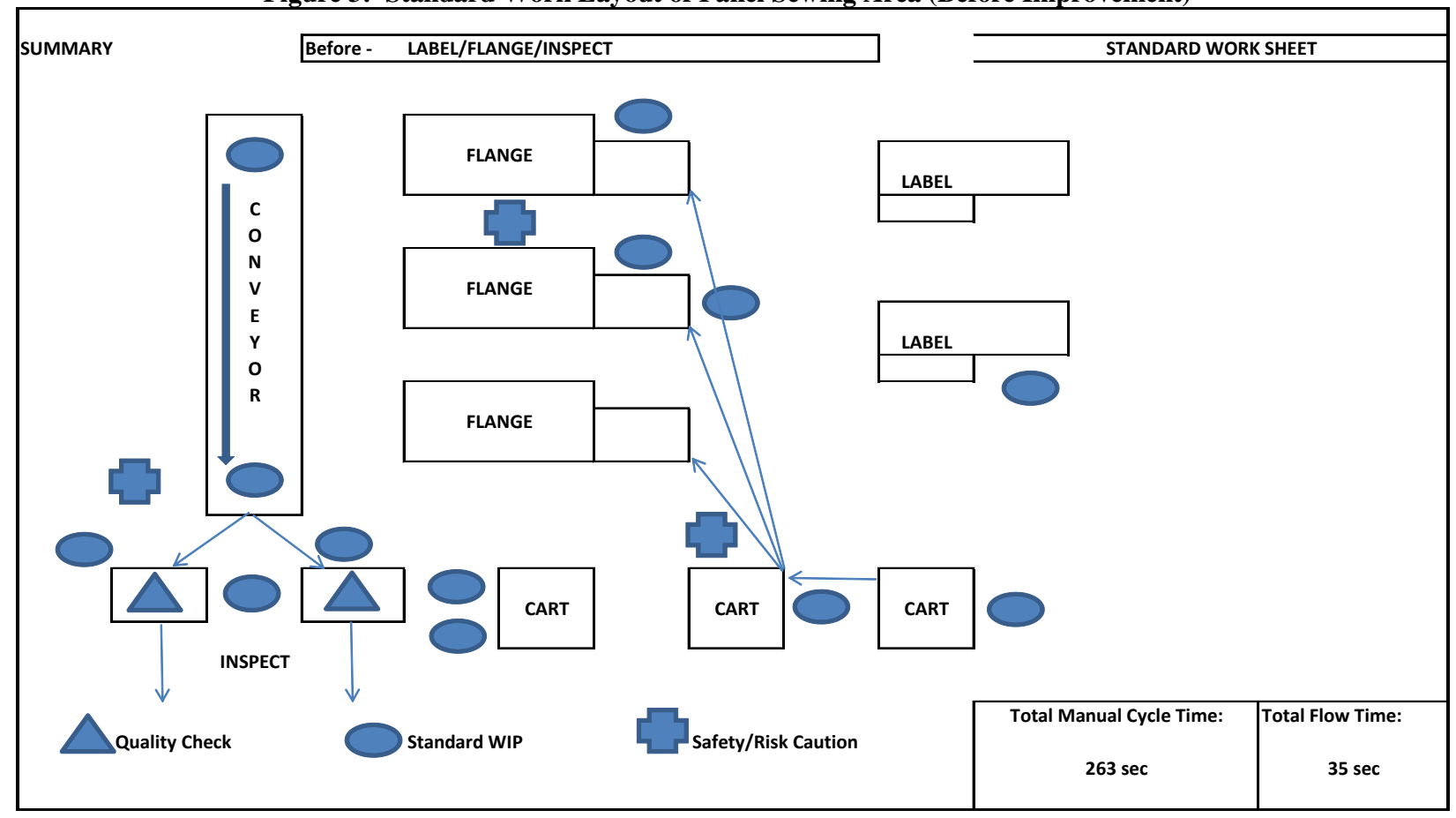

The arrows in Figure 3 indicate the movement needed by the operators to move material between the various operations. All work sequences need to be represented and staffing levels confirmed. Work sequences can then be drawn for each person.

Spaghetti diagrams isolate operator movements that occur to complete their tasks. By following the operator's movements with a pen on the layout sheet, Figure 4 shows the spaghetti diagram of the operator's movement. It shows repetitive movements as material is placed on the cart and moved to the flange operation. More repetitive movements are shown moving materials off the conveyor into the inspection stations. Spaghetti diagrams are useful in identifying how to change the layout of an area to minimize walking and other non-value activities.

By using the information in Figures 2-4, a new layout can be designed minimizing non-value activities while maintaining takt time (Figure 5). After the new layout is designed, another time observation chart is completed for cycle times necessary to maintain one-piece flow, minimize WIP and ensure takt time is met. Total crew was reduced by 3 , increasing productivity by $45 \%$. Also, WIP inventory has been reduced by $50 \%$. 
Figure 4: Spaghetti Diagram of Panel Sewing Area (Before Improvement)

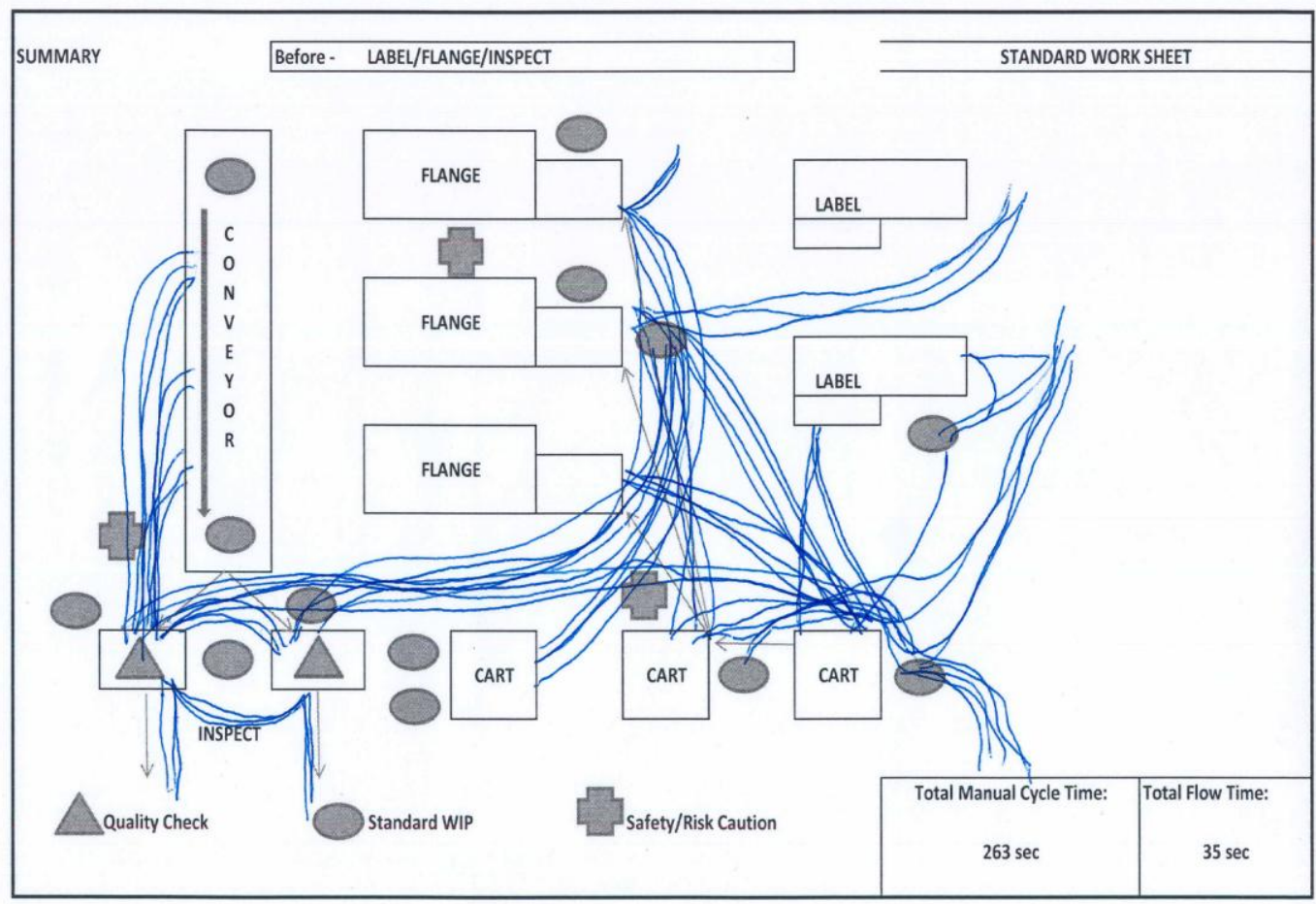

Figure 5: Standard Work Layout of Panel Sewing Area (After Improvement)

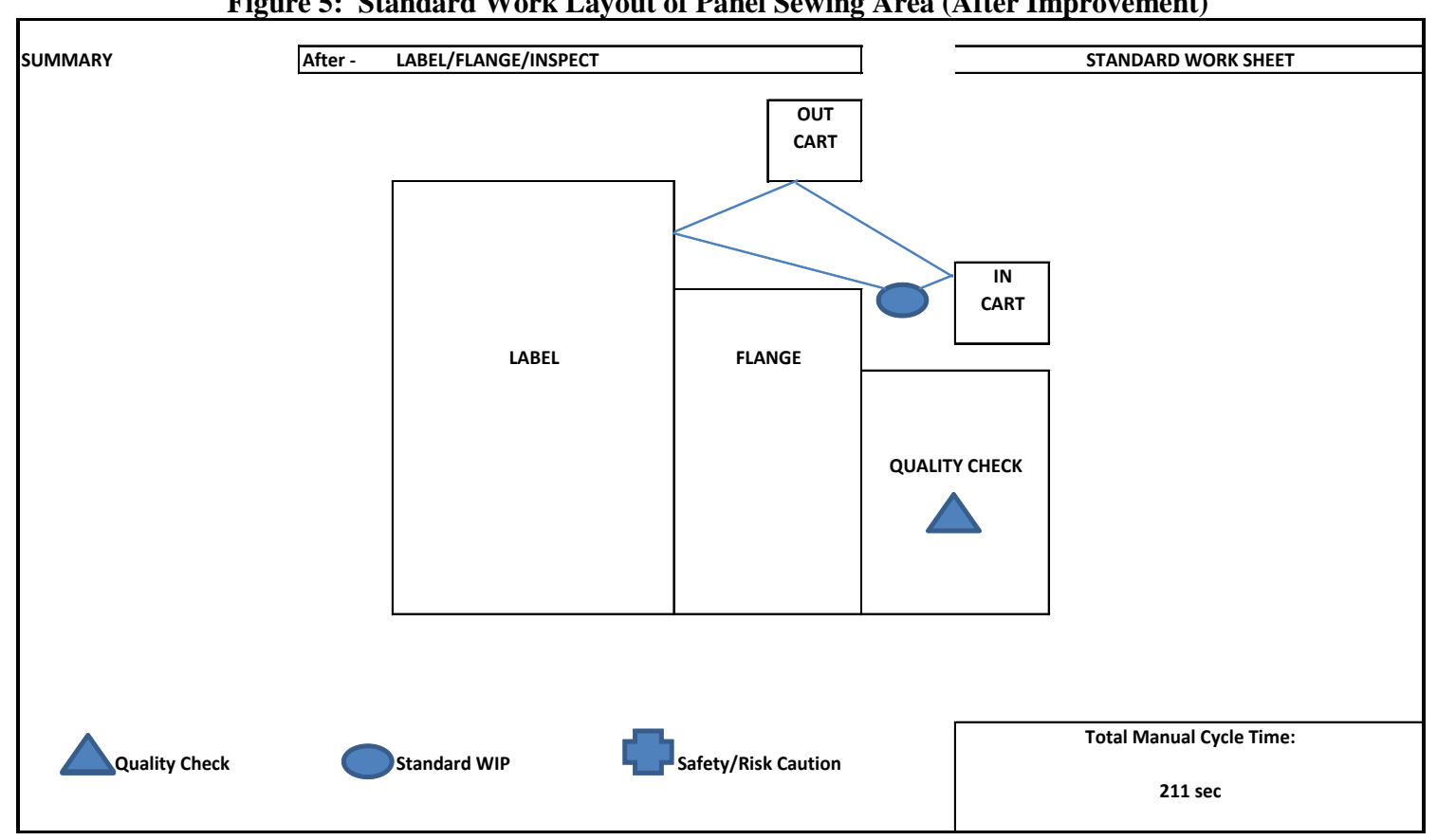




\section{6-S Audit Sheet}

An assessment called the 6-S Audit Sheet is useful to identify improvement opportunities that relate to:

- $\quad$ Sorting (getting rid of the unneeded)

- $\quad$ Straightening (organizing the area)

- $\quad$ Scrubbing (cleaning, seeing, solving)

- $\quad$ Safety (identify/solve risks)

- $\quad$ Standardizing (documenting who does what)

- $\quad$ Sustaining (daily self discipline)

A copy of the before 6-S Audit Sheet is shown in Figure 6. The goal is to score 25 "yes" responses, or $100 \%$ score. The before score indicates only 5 "yes" answers, or 20\%. By redesigning the area and posting standard work information on the documentation board, the 6-S Audit score was increased to $84 \%$, or an improvement of $320 \%$ from baseline.

Figure 6: 6-S Audit Sheet (Before Improvements)

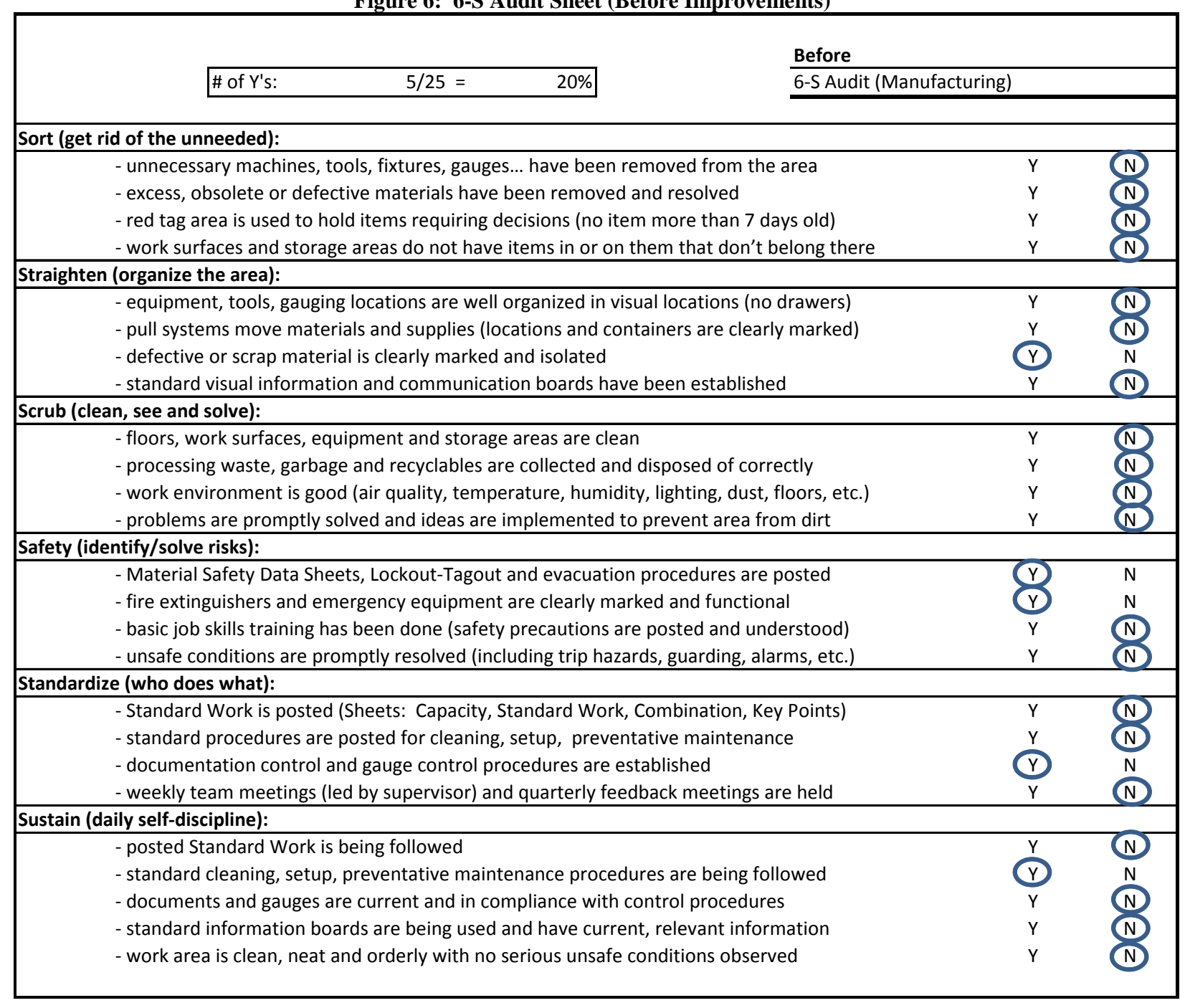




\section{Standard Work Combination Sheet}

The Standard Work Combination Sheet is intended to clearly document the assignments of each person by listing the tasks in the work sequence. It lists the unattended machine run and walk times. An example is shown in Figure 7. This sheet documents the work sequence and can be used to monitor performance and train new personnel.

Figure 7: Standard Work Combination Sheet for Panel Sewing Area (After Improvement)

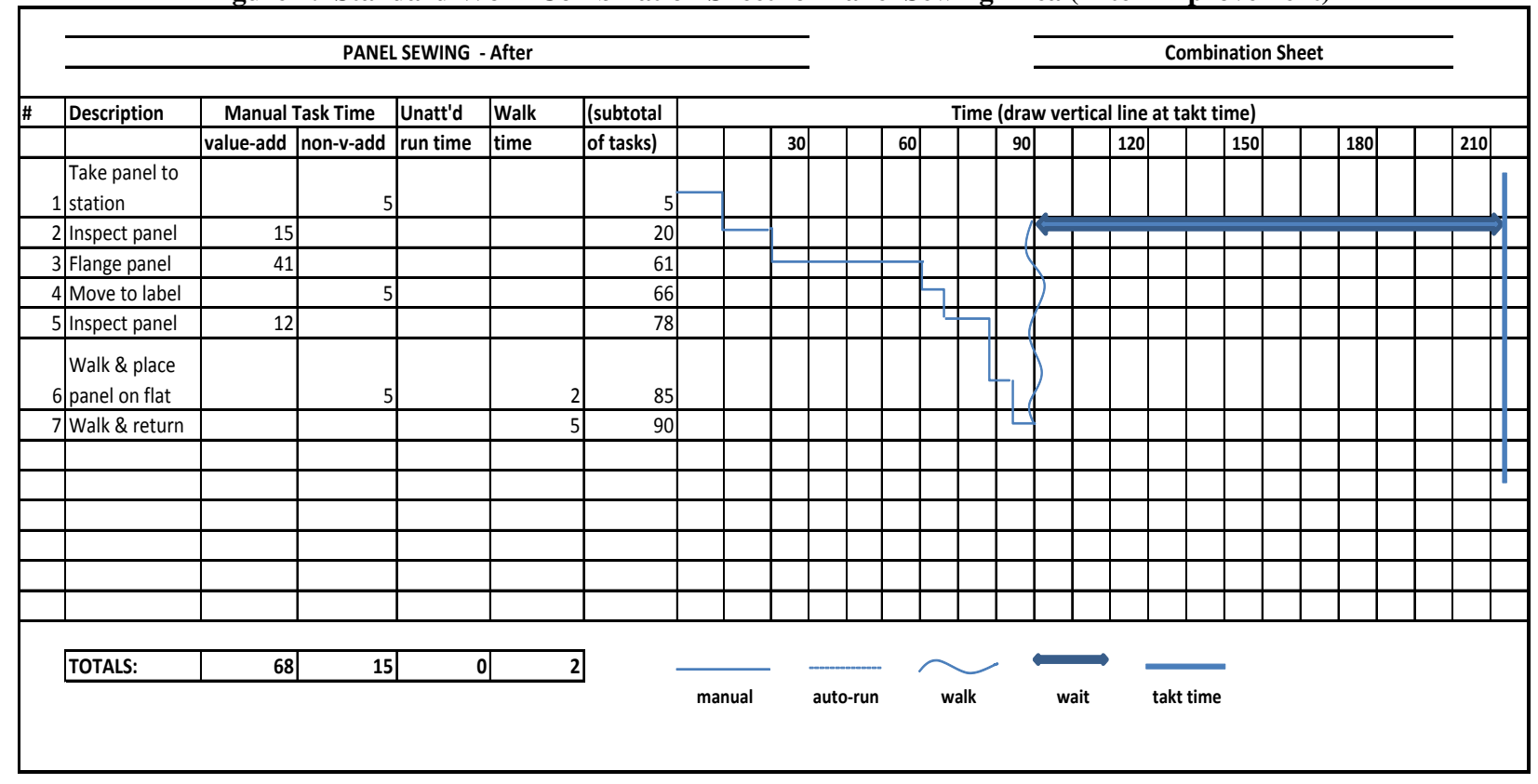

\section{Goals Achieved}

Table 2 shows the final results of the Kaizen event compared to baseline and target. Additional improvements were also made in parts travel and employee walking distance.

Table 2: Summary of Kaizen Improvements Made

\begin{tabular}{|l|c|c|c|}
\hline Description & Baseline & Target & Final Result \\
\hline WIP Inventory & 2,000 pieces & $\begin{array}{c}1,600 \text { pieces (20\% } \\
\text { improvement) }\end{array}$ & $\begin{array}{c}1,000 \text { pieces }(50 \% \\
\text { improvement) }\end{array}$ \\
\hline Productivity & 6 pieces/labor hour & 8 pieces/labor hour & 11 pieces/labor hour \\
\hline 6-S Audit & $20 \%$ & $100 \%$ & $54 \%$ \\
\hline Safety Improvements & 0 & 5 & 5 \\
\hline Quality Improvements & 0 & 5 & 5 \\
\hline Parts Travel Distance & 52 feet & -- & 2 feet \\
\hline Employee Walking Distance & 33 feet & -- & 2 feet \\
\hline
\end{tabular}

\section{SUSTAINING THE GAINS}

\section{Documenting Standard Work}

Documenting and posting standard work is often one of the last exercises a Kaizen team will implement. In addition, all employees along with the supervisor(s) of the area need to be trained in standard work. Supervisors 
should periodically assess how well standard work is being followed as well as coach employees through any obstacles that prevent standard work from being consistently followed. The use of a Production Control Board is a good tool to monitor and document issues as discovered (see Figure 8).

Figure 8: Production Control Board for the Sewing Panel Area

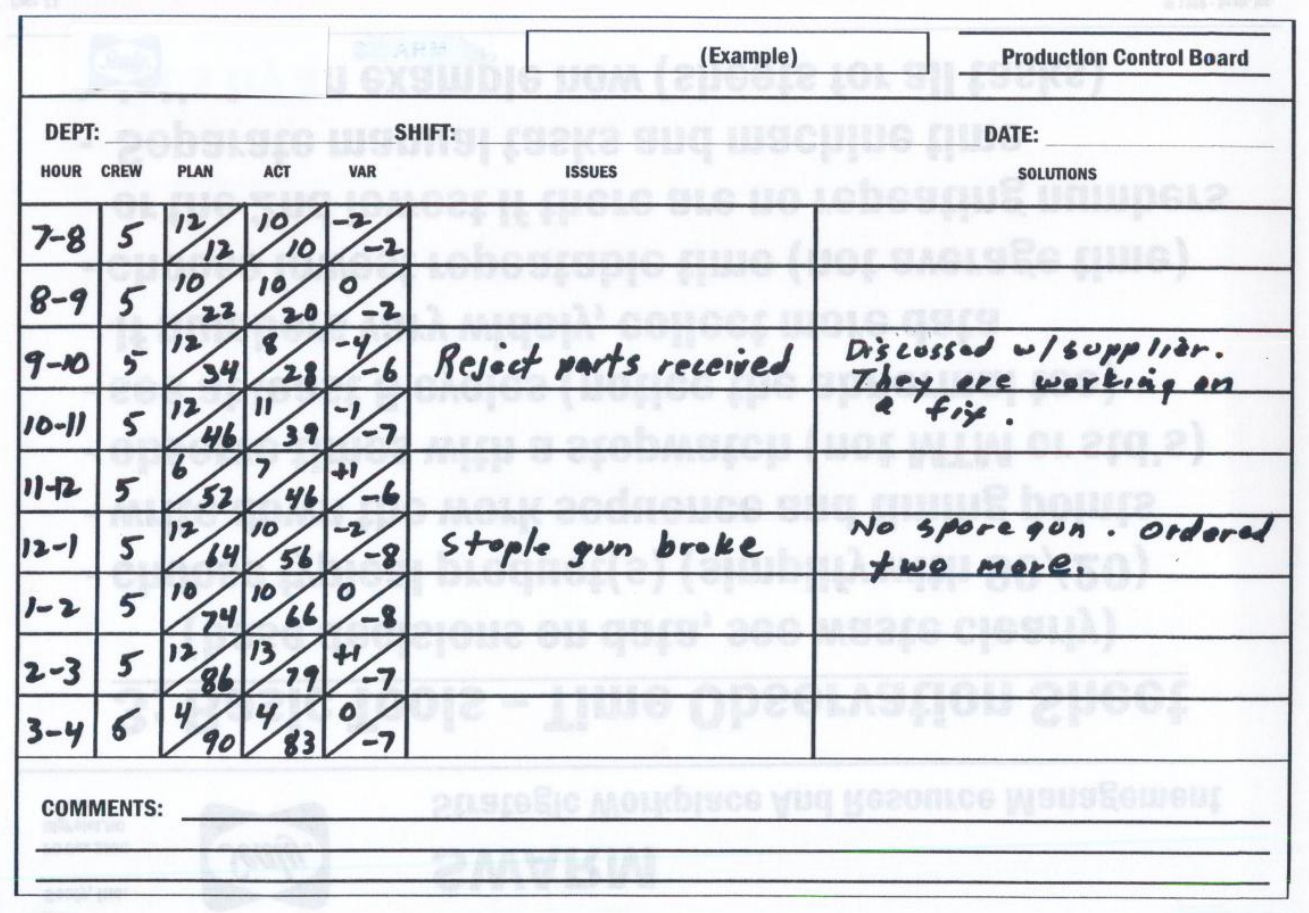

Another sheet to post permanently in the production area is a Key Points Sheet. This sheet highlights important aspects of work sequence so that standard work can be consistently maintained. For example, one key point for the Sewing Panel Area may be to "Place panel in flange machine making certain that dimple is in front (facing towards you)" to begin flange operation. Note: Make certain air pressure is set to 60 psi."

\section{Cell Documentation Board}

A board should be placed in the improved work area that posts the "after improvement" standard work sheets. These should include at a minimum:

- $\quad$ Standard Work Layout Diagram

- $\quad$ Production Control Board

- $\quad$ Standard Work Combination Sheet (one for each operator) as needed.

In addition, the Key Points Sheet should be placed near each work station so operators can easily refer to it

\section{Summary}

The use of kaizen events has increased significantly in recent years (Bane, 2002), with its success only being limited by knowledge of the tools and organizational commitment to sustaining the gains. This paper seeks to add to the knowledge stream by providing examples of Kaizen standard work tools aimed at process improvement. 


\section{AUTHOR INFORMATION}

Elaine Labach is currently an Assistant Professor of Management at Troy University. She graduated with a PhD in operations management from Indiana University and has worked as a consultant with several manufacturing and service firms. Her main research interests are process improvement in manufacturing and service organizations, and the development and use of case studies.

\section{REFERENCES}

1. Bane, R. (2002). Leading Edge Quality Approaches in Non-Manufacturing Organizations. ASQ's Annual Quality Congress Proceedings, May 20-22, 245-249.

2. Bradley, J. \& Willett, J. (2004). Cornell Students Participate in Lord Corporation's Kaizen Projects, Interfaces, 34, 451-459.

3. Cuscela, K. (1998). Kaizen Blitz Attacks Work Processes at Dana Corporation, IIE Solutions, 30, 29-31.

4. Doolen, T., VanAken, E., Farris, J., Worley, F. \& Huwe, J. (2008). Kaizen Events and Oraganizational Performance: A Field Study, International Journal of Productivity and Performance Management, 57, 637-658.

5. Melnyk, S., Calatone, R., Montabon, F. \& Smith, R. (1998). Short Term Action in Pursuit of Long-Term Improvements: Introducing Kaizen Events. Production \& Inventory Management Journal, 39, 69-76.

6. Sheridan, J. (1997). Kaizen Blitz. Industry Week/IW, 246, 18-27.

7. Vasilash, G. (1997). Getting Better - Fast! Automotive Manufacturing \& Production, 109, 66-68. 
NOTES 